\title{
POPULATION DENSITY ON COWPEA CULTIVARS WITH DIFFERENT GROWTH HABITS IN THE MATOPIBA REGION ${ }^{1}$
}

\author{
MILTON JOSÉ CARDOSO* ${ }^{*}$, FRANCISCO DE BRITO MELO ${ }^{3}$, VALDENIR QUEIROZ RIBEIRO $^{4}$
}

\begin{abstract}
The aim of this study was to assess the productive performance of cowpea cultivars with different growth habits as a function of population density in the MATOPIBA region, Brazil. The experiments were carried out in Magalhães de Almeida, MA in the agricultural season 2014/2015. The cultivars BRS Itaim, BRS Tumucumaque, and BRS Pajeú, which present an erect, semi-erect, and semi-prostrate growth habits, respectively, were assessed. For the erect and semi-erect cultivars, a total of $8,12,16,20$, 24, and 28 plants $^{-2}$ were used whereas for the semi-prostrate cultivar, a total of $2,6,10,14,18$, and 22 plants $\mathrm{m}^{-2}$ were used. The experimental design was a randomized block design with four replications and treatments composed of plant densities. Grain yield and number of pods per area presented a quadratic response to the increased plant density whereas a decreasing linear response was observed for the number of pods per plant. The maximum grain yield of erect, semi-erect, and semi-prostrate cultivars were $1,076 \mathrm{~kg} \mathrm{ha}^{-1}\left(19.5\right.$ plants m$\left.^{-2}\right), 1,252 \mathrm{~kg} \mathrm{ha}^{-1}$ (18.7 plants $\left.\mathrm{m}^{-2}\right)$, and $755 \mathrm{~kg} \mathrm{ha}^{-1}\left(14.5\right.$ plants $\left.\mathrm{m}^{-2}\right)$, respectively. The number of pods per area was the character that most correlated $(\mathrm{P}<0.01)$ with grain yield, regardless of the plant growth habit.
\end{abstract}

Keywords: Plant architecture. Cultivar. Vigna unguiculata.

\section{DENSIDADE POPULACIONAL EM CULTIVARES DE FEIJÃO-CAUPI COM DIFERENTES PORTES DE PLANTA, NA REGIÃO DO MATOPIBA}

RESUMO - O objetivo deste trabalho foi avaliar o desempenho produtivo de cultivares de feijão-caupi de diferentes tipos de porte da planta, em função da densidade populacional, na região do MATOPIBA. Os experimentos foram conduzidos no município de Magalhães de Almeida, MA, ano agrícola 2014/2015. Foram avaliadas as cultivares BRS Itaim, de porte ereto, BRS Tumucumaque, de porte semiereto e BRS Pajeú, de porte semiprostrado. Para as cultivares de portes ereto e semiereto utilizaram-se $8 ; 12 ; 16 ; 20 ; 24$ e 28 plantas $^{-2}$ e para a cultivar de porte semiprostado de $2 ; 6 ; 10 ; 14 ; 18$ e 22 plantas $\mathrm{m}^{-2}$. O delineamento experimental foi o de blocos casualizados com quatro repetições e os tratamentos constituídos pelas densidades de plantas. Os rendimentos de grãos e o número de vagens por área responderam quadraticamente ao aumento da densidade de plantas, enquanto resposta linear decrescente foi observada para o número de vagens por planta. Os rendimentos de grãos máximos das cultivares de portes ereto e semiereto foram, respectivamente, de $1.076 \mathrm{~kg} \mathrm{ha}^{-1}(19,5$ plantas $\left.\mathrm{m}^{-2}\right)$ e $1.252 \mathrm{~kg} \mathrm{ha}^{-1}\left(18,7\right.$ plantas $\left.\mathrm{m}^{-2}\right)$ e para a cultivar de porte semiprostrado foi de $755 \mathrm{~kg} \mathrm{ha}^{-1}(14,5$ plantas $\left.\mathrm{m}^{-2}\right)$. $\mathrm{O}$ número de vagens por área foi o caráter mais correlacionado $(\mathrm{P}<0,01)$ com o rendimento de grãos, independentemente do tipo de porte da planta.

Palavras-chave: Arranjo de plantas. Cultivar. Vigna unguiculata.

\footnotetext{
${ }^{*}$ Corresponding author

${ }^{1}$ Received for publication in $08 / 23 / 2016$; accepted in $03 / 30 / 2017$

Paper approved from IV CONAC 2016.

${ }^{2}$ Embrapa Meio-Norte, Plant Production Group, Plant Science, Piauí, PI, Brazil; milton.cardoso@embrapa.br.

${ }^{3}$ Embrapa Meio-Norte, Natural Resources Group, Soil Fertility and Plant Nutrition, Piauí, PI, Brazil; fracisco.brito@embrapa.br.

${ }^{4}$ Embrapa Meio-Norte, Plant Production Group, Experimental Statistics, Piauí, PI, Brazil; valdenir.queiroz@embrapa.br.
} 


\section{INTRODUCTION}

The largest Brazilian areas sown to cowpea are within the Northeastern region. These areas play an important socio-economic role since this crop is the main local source of protein, mainly for the rural population, in addition to providing the workforce. Local rainfall regime is quite irregular, which causes the phenomenon known as a dry spell. When occurring during crop critical period, it affects food production, mainly due to the use of non-bred cultivars and inadequate number of plants, which depends on a season with rains well-distributed (JALLOW; FERGUSON, 1985; TÁVORA; NOGUEIRA; PINHO, 2001; CARDOSO; RIBEIRO, 2006; QASEM; BIFTU, 2010; CARDOSO; RIBEIRO; BASTOS, 2015).

Developing cultivars with high potential for grain yield and an adequate plant architecture for dense cultivation and mechanized harvest aims to meet the requirements of technified systems. Such characters enable cowpea cultivation in large areas in either season or off-season, especially in the MATOPIBA regions - Brazil, where there has been a significant increase in the planted. Grain yield increments in response to higher plant densities have been reported by Cardoso and Ribeiro (2006), Bezerra et al. (2008), Njoku and Muoneke (2008), Makoi, Chimphango and Dakora (2009), Naim and Jabereldar (2010), Cox and Cherney (2011), Santos (2014), and Cardoso, Ribeiro and Bastos (2015).

Plant density management has as the main objective to increase canopy efficiency in intercepting the incident radiation in relation to time and unit area. Oroka and Omoregie (2007) emphasize that increases in plant density of cowpea can increase solar radiation interception and its use efficiency. Mendes et al. (2005) observed that the percentage of intercepted light and leaf area index of cowpea increased by $50 \%$ and $206.5 \%$, respectively, when plant density was increased from 41,666 to $166,666 \mathrm{ha}^{-1}$.

The expression of cowpea productive potential depends on a favorable combination of a set of factors, standing out the number of plants per area, which directly influences the morphological, physiological, and grain yield characteristics, and the use of technological, environmental, and management resources (BEZERRA et al., 2012).

In cultivation systems, whether technified or traditional, there is a need for information on the changes that occur in the physiology and production components of modern cowpea cultivars when submitted to different plant densities. Thus, the aim of this study was to assess the productive performance of cowpea cultivars with different growth habits as a function of population density in the MATOPIBA region, Brazil.

\section{MATERIAL AND METHODS}

The experiments were conducted in an Oxisol (JACOMINE et al., 2013) under a rainfed regime in the agricultural season 2014/2015, from March to April 2015. The experimental area was located at the Cajuí Catuí farm, in the micro-region of Baixo Parnaíba Maranhense, in Magalhães de Almeida, MA, Brazil, at the geographical coordinates $3^{\circ} 20^{\prime} 56^{\prime \prime} \mathrm{S}$ and $42^{\circ} 19^{\prime \prime} 42^{\prime \prime} \mathrm{W}$, with an altitude of 103 meters. Soil samples were collected at a depth of $20 \mathrm{~cm}$ and submitted to chemical analysis at the Laboratory of Soil Fertility of the Embrapa Mid-North. These samples presented a $\mathrm{pH}$ in water $(1: 2.5)=5.1$, phosphorus $\left.(\mathrm{mg} \mathrm{dm})^{-3}\right)=12.1$, potassium $\left.(\mathrm{mg} \mathrm{dm})^{-3}\right)=45.2$, calcium $\left(\right.$ cmolc $\left.\mathrm{dm}^{-3}\right)=1.01$, magnesium $\left(\right.$ cmolc $\left.\mathrm{dm}^{-3}\right)=0.32$, aluminum $\left(\right.$ cmolc $\left.\mathrm{dm}^{-3}\right)=0.0$, and organic matter $\left(\mathrm{g} \mathrm{kg}^{-1}\right)=10.1$.

Three field experiments were carried out. The first experiment with the cultivar BRS Itaim, which has an erect growth habit (ER), the second with the cultivar BRS Tumucumaque, which has a semi-erect growth habit (SE), and the third with the cultivar BRS Pajeú, which has a semi-prostrate growth habit (SP). In the experiments with the cultivars ER and SE, the studied densities were 12, 16, 20, 24, and 28 plants $\mathrm{m}^{-2}$ whereas, in the experiment with the cultivar SP, densities were $6,10,14,18$, and 22 plants $\mathrm{m}^{-2}$. In all cases, the experimental design was a randomized block design with four replications. Plots were composed of four rows of five meters. The useful area consisted of the two central rows. Treatments consisted of five plant densities.

Sowing was carried out on March 25, 2015, with excess seeds in the rows. Thinning was performed after emergence in order to maintain only the assessed plant densities. Broadcasting fertilization corresponded to $250 \mathrm{~kg}$ of single superphosphate and $50 \mathrm{~kg}$ of potassium chloride per hectare. At 15 days after sowing, a topdressing fertilization was conducted with $100 \mathrm{~kg}$ of ammonium sulfate per hectare.

The rainfall registered during the crop cycle was $441 \mathrm{~mm}$. Water stress occurred during flowering and filling-pod stages. These development stages occurred in May, with $66 \mathrm{~mm}$ of rainfall (3 rainy days and 28 dry days).

The assessed agronomic characters were pod length (PL), number of grains per pod (NGP), number of pods per plant (NPP), number of pods per area (NPA), mass of one hundred grains (MHG) (in grams), and grain weight (GW) (in $\mathrm{kg} / \mathrm{useful}$ area), corrected for $13 \%$ moisture using the following equation: $[(100-\mathrm{Mi}) \times \mathrm{GW}] \div(100-\mathrm{Mf})$, where $\mathrm{Mi}$ is the current moisture of grains and Mf is the desired moisture (13\%). The first four characters were obtained in ten pods chosen at random at the useful area 
of each treatment. Grain weight per plant was determined by dividing the grain yield by the number of plants in the useful area. Grain yield $\left(\mathrm{kg} \mathrm{ha}{ }^{-1}\right)$ was calculated as $\mathrm{GY}=\left(10,000 \mathrm{~m}^{2} \times \mathrm{GWC}\right) \div$ useful plot area $\left(\mathrm{m}^{2}\right)$, where GWC is the grain weight in the useful plot area corrected to $13 \%$ moisture $(\mathrm{kg})$.

Regression analysis was used in the analysis of variance, with first- and second-degree models for plant densities, according to the method of Pimentel-Gomes (2009) and Zimmermann (2014). The best model was selected considering the t-test and the significance of each parameter, within a limit up to $15 \%$ probability (CONAGIN; JORGE, 1982).

The method of Alvarez and Alvarez (2003) was also used. This method states that for an equation to be significant, it is unnecessary that all coefficients be significant but the model significance must be explicit in the equation (in each regression coefficient), and not only with the significance of $\mathrm{R}^{2}$.

Pearson's correlation coefficients of grain yield were determined in relation to the production characters. All statistical analyses were performed using the software SAS (SAS INSTITUTE, 2015).

\section{RESULTS AND DISCUSSION}

Regardless of the growth habits of the assessed cowpea cultivars, the analysis of variance showed significant effects for plant densities related to the characters number of pods per plant, number of pods per area, and grain yield. The characters pod length, number of grains per pod, and mass of one hundred grains showed no significance (Table 1).

Table 1. Analysis of variance of pod length (PL), square root of number of grains per pod (SRNGP), grain yield per hectare $(\mathrm{GYH})$, mass of one hundred grains (MHG), square root of number of pods per plant (SRNPP), and square root of number of pods per area (SRNPA) of the cowpea cultivars BRS Itaim, BRS Tumucumaque, and BRS Pajeú.

\begin{tabular}{|c|c|c|c|c|c|c|}
\hline $\begin{array}{l}\text { Source of } \\
\text { variation }\end{array}$ & PL & SRNGP & $\mathrm{GYH}$ & MHG & SRNPP & SRNPA \\
\hline & \multicolumn{6}{|c|}{ BRS Itaim } \\
\hline $\mathrm{BL}$ & $0.8878^{\mathrm{ns}}$ & $0.058^{\mathrm{ns}}$ & $39680.44 * *$ & $2.1120^{\mathrm{ns}}$ & $0.0471 *$ & $0.6009 * *$ \\
\hline PD & $0.3410^{\mathrm{ns}}$ & $0.0014^{\mathrm{ns}}$ & $107890.80^{* *}$ & $0.9353^{\text {ns }}$ & $0.6351 * *$ & $1.3826^{* *}$ \\
\hline CV (\%) & 4.39 & 4.67 & 6.07 & 3.67 & 2.44 & 1.63 \\
\hline \multirow[t]{2}{*}{ Mean } & 15.40 & 3.25 & 934.00 & 22.31 & 2.07 & 7.83 \\
\hline & \multicolumn{6}{|c|}{ BRS Tumucumaque } \\
\hline $\mathrm{BL}$ & $0.3908^{*}$ & $0.0176^{\mathrm{ns}}$ & $76452.00 * *$ & $0.8129^{\mathrm{ns}}$ & $0.0033^{\mathrm{ns}}$ & $0.0583^{\mathrm{ns}}$ \\
\hline PD & O.7195* & $0.0166^{\mathrm{ns}}$ & $133345.07 * *$ & 1.7734 & $0.5328 * *$ & $2.4704 * *$ \\
\hline CV (\%) & 1.56 & 13.84 & 5.31 & 3.25 & 3.98 & 1.94 \\
\hline \multirow[t]{2}{*}{ Mean } & 18.79 & 3.58 & 1079.67 & 19.15 & 1.89 & 7.14 \\
\hline & \multicolumn{6}{|c|}{ BRS Pajeú } \\
\hline $\mathrm{BL}$ & $0.7869 *$ & $0.0283^{*}$ & $11483.78 *$ & $0.5000^{\mathrm{ns}}$ & $0.0862 *$ & $0.7647 * *$ \\
\hline PD & $1.1765^{* *}$ & $0.0040^{\mathrm{ns}}$ & $90204.50 * *$ & $1.1000^{\mathrm{ns}}$ & $2.7447 * *$ & $4.1976 * *$ \\
\hline CV (\%) & 2.19 & 1.08 & 9.00 & 3.49 & 7.11 & 5.29 \\
\hline Mean & 17.86 & 3.90 & 634.50 & 20.25 & 2.51 & 6.87 \\
\hline
\end{tabular}

$* *(\mathrm{p}<0.01)$ and $*(\mathrm{P}<0.05)$ : significant at the $1 \%$ and $5 \%$ level, respectively; ns: non-significant by the $\mathrm{F}$-test. BL: Blocks; PD: planting density.

The number of pods per plant responded in a linearly decreasing manner whereas the number of pods per area presented a quadratic response with the increased plant density (Table 2). This linear decrease in the number of pods per plant indicates that for each increase of one cowpea plant per square meter, a decrease of $0.213,0.166$, and 0.378 pods per plant was observed for the erect, semi-erect, and semi-prostrate growth habits, respectively. In addition, the number of pods per area reached a maximum of 70.12 pods $\mathrm{m}^{-2}$ with 19.6 plants $\mathrm{m}^{-2}$ for the erect growth habit, 62.6 pods $\mathrm{m}^{-2}$ with 19.4 plants $\mathrm{m}^{-2}$ for the semi-erect growth habit, and 59.22 pods $\mathrm{m}^{-2}$ with 15.6 plants $\mathrm{m}^{-2}$ for the semi-prostrate growth habit. Similar behavior was also observed by Olufajo and Singh (2002), Naim and Jabereldar (2010), and Cardoso, Ribeiro and Bastos (2015). Intraspecific competition, as well as phenotypic plasticity, may have been one of the reasons for these scenarios, probably because of the decrease in flower formation, which should have been aggravated due to water stresses that occurred during flowering and pod-filling stages (LEMMA; WORKU; WOLDERMICHAEL, 2009). Similar results were observed by Távora, Nogueira and Pinho (2001), Bezerra et al. (2009), Naim and Jabereldar (2010), Naim et al. (2012), and Cardoso, Ribeiro and Bastos (2015). 
Table 2. Response equations of cowpea cultivars with erect (BRS Itaim), semi-erect (BRS Tumucumaque), and semi-prostrate (BRS Pajeú) growth habits as a function of plant density.

\begin{tabular}{|c|c|c|c|c|}
\hline $\begin{array}{c}\text { Character } \\
\text { (Y) }\end{array}$ & Equation & $\begin{array}{c}\mathrm{X} \\
\text { maximum }\end{array}$ & $\begin{array}{c}\mathrm{Y} \\
\text { maximum }\end{array}$ & $\overline{\mathrm{R}^{2}}$ \\
\hline & BRS Itaim & & & \\
\hline GYH & $-2.873^{* *} \mathrm{x}^{2}+112.9^{* *} \mathrm{x}-33.47$ & 19.7 & 1.076 & $0.77^{*}$ \\
\hline NPA & $-0.170^{* *} x^{2}+6.65^{* *} x+5.01$ & 19.6 & 70.12 & $0.79 * *$ \\
\hline \multirow[t]{2}{*}{ NPP } & $-0.213^{* *} \mathrm{x}+8.26$ & - & - & $0.97 * *$ \\
\hline & BRS Tumucumaque & & & \\
\hline GYH & $-3.67^{* *} x^{2}+137.6^{* *} x+36.48$ & 18.7 & 1.222 & $0.82 * *$ \\
\hline NPA & $-0.223^{* *} x^{2}+8.63^{* *} x-20.91$ & 19.4 & 62.6 & $0.92 * *$ \\
\hline \multirow[t]{2}{*}{ NPP } & $-0.166^{* *} x+6.68$ & - & - & $0.93 * *$ \\
\hline & BRS Pajeú & & & \\
\hline GYH & $-2.274^{* *} x^{2}+66.10^{* *} x+275.10$ & 14.5 & 785 & $0.77 *$ \\
\hline NPA & $-0.185^{* *} x^{2}+5.77^{* *} x+14.27$ & 15.6 & 59.22 & $0.86^{* *}$ \\
\hline NPP & $-0.378^{* *} \mathrm{x}+10.04$ & - & - & $0.97 * *$ \\
\hline
\end{tabular}

${ }^{* *}=(\mathrm{P}<0.01)$ and ${ }^{*}=(\mathrm{P}<0.05)$ by the t-test. GYH: grain yield per hectare; NPA: number of pods per area; NPP: number of pods per plant.

The increase in cowpea plant density provided a quadratic response for grain yield (Table 2 ), with maximum values of $1,076,1,222$, and $785 \mathrm{~kg} \mathrm{ha}^{-1}$ obtained, respectively, for densities of 19.7 (ER), 18.7 (SE), and 14.5 plants $\mathrm{m}^{-2}$ (SP). Similar results were observed by Cardoso and Ribeiro (2006), Naim and Jabereldar (2010), and Cardoso, Ribeiro and Bastos (2015). However, Jallow and Ferguson (1985) observed linear effects by varying plant density from 4 to 25 plants $\mathrm{m}^{-2}$ in eight cowpea cultivars and Mendes et al. (2005) with plant densities varying from 16.6 to 41.6 plants $\mathrm{m}^{-2}$.

The number of pods per area was the character most correlated $(\mathrm{P}<0.01)$ with grain yield, reaching values of $0.98,0.97$, and 0.99 for cowpea with erect, semi-erect, and semi-prostrate growth habits, respectively (Table 3 ).

Table 3. Estimates of Pearson's correlation coefficients of grain yield (GY) in relation to pod length, number of grains per pod, number of pods per plant, number of pods per area, and mass of one hundred grains (MHG) of cowpea cultivars with erect, semi-erect, and semi-prostrate growth habits in the MATOPIBA region.

\begin{tabular}{cccc}
\hline Character & BRS Itaim & BRS Tumucumaque & BRS Pajeú \\
\hline Pod length & $0.2823^{\text {ns }}$ & $0.4811^{\text {ns }}$ & $-0.0474^{\text {ns }}$ \\
Number of grains per pod & $0.0425^{\text {ns }}$ & $-0.2602^{\text {ns }}$ & $0.0110^{\text {ns }}$ \\
Number of pods per plant & $-0.1685^{\text {ns }}$ & $0.0109^{\text {ns }}$ & -0.4968 \\
Number of pods per area & $0.9751^{* *}$ & $0.9727^{* *}$ & $0.9853^{* *}$ \\
Mass of one hundred grains & $0.3175^{\text {ns }}$ & $-0.1971^{\text {ns }}$ & $-0.1099^{\text {ns }}$ \\
\hline
\end{tabular}

$* *=(\mathrm{P}<0.01)$; ns: non-significant by the t-test.

\section{CONCLUSIONS}

An increase in plant density influences grain yield of cowpea with erect, semi-erect, and semi-prostrate growth habits, following a quadratic relation with a maximum of 19.7 (1,076 kg ha $\left.{ }^{-1}\right), 18.7\left(1,222 \mathrm{~kg} \mathrm{ha}^{-1}\right)$, and 14.5 $\left(785 \mathrm{~kg} \mathrm{ha}^{-1}\right)$ plants $\mathrm{m}^{-2}$, respectively. The number of pods per area is the character that most contributes to the differences in grain yield of cowpea in relation to plant densities.

\section{REFERENCES}

AlVAREZ ,V. H.; AlVAREZ, G. A. M. Apresentação de equações de regressão e suas interpretações. Boletim Informativo da Sociedade Brasileira de Ciência do Solo, Viçosa, v. 28, n. 3, p.
28-32, 2003.

BEZERRA, A. A. C. et al. Morfologia e produção de grãos em linhagens modernas de feijão-caupi submetidas a diferentes densidades populacionais. Revista de Biologia e Ciências da Terra, Aracaju, v. 8, n. 1, p. 85-93, 2008.

BEZERRA, A. A. C. et al. Características de dossel e de rendimento em feijão-caupi ereto em diferentes densidades populacionais. Pesquisa Agropecuária Brasileira, Brasília, v. 44, n. 10, p. 1239-1245, 2009.

BEZERRA, A. A. C. et al. Comportamento morfoagronômico de feijão-caupi, cv. BRS Guariba, sob diferentes densidades de plantas. Revista de Ciências Agrárias, Belém, v. 55, n. 3, p. 184-189, 2012. 
CARDOSO, M. J.; RIBEIRO, V. Q. Desempenho agronômico do feijão-caupi, cv. Rouxinol, em função de espaçamentos entre linhas e densidades de plantas sob regime de sequeiro. Revista Ciência Agronômica, Fortaleza, v. 37, n. 1, p. 102-105, 2006.

CARDOSO, M. J.; RIBEIRO, V. Q.; BASTOS, E. A. Densidades de plantas de feijão-caupi de porte semi-prostrado sob irrigação. Teresina: Embrapa Meio-Norte, 2015. 21 p. (Embrapa Meio-Norte. Boletim de Pesquisa e Desenvolvimento, 110).

CONAGIN, A.; JORGE, J. P. N. Delineamento (1/5) $(5 \times 5 \times 5)$ em blocos. Bragantia, Campinas, v. 41, n. 16, p. 155-168, 1982.

COX, W. J.; CHERNEY, J. H. Growth and yield responses of soybean to row spacing and seeding rate. Agronomy Journal, Madison, v. 103, n. 1, p. 123-128, 2011.

JACOMINE, P. K. T. et al. Sistema brasileiro de classificação de solos. 3. ed. Brasília, DF: Embrapa, 2013. 353 p.

JALLOW, A. T.; FERGUSON, T. U. Effects on planting density and cultivar of seed yield of cowpeas (Vigna unguiculata (L.) Walp.) in Trinidad. Tropical Agriculture, St. Augustine, v. 62, n. 2, p. 121-124, 1985.

LEMMA, G.; WORKU, W.; WOLDERMICHAEL, A. Moisture and planting density interactions affect productivity in cowpea (Vigna unguiculata). Journal of Agronomy, Dubai, v. 8, n. 4, p. 117-123, 2009.

MAKOI, J. H. J. R.; CHIMPHANGO, S. B. M.; DAKORA, F. D. Effect of legume plant density and mixed culture on symbiotic N2 fixation in five cowpea [Vigna unguiculata (L.) Walp.] genotypes in South Africa. Symbiosis, Amsterdam, v. 48, n. 1, p. 57-67, 2009.

MENDES, R. M. S. et al. Alterações na relação fonte-dreno em feijão-de-corda submetido a diferentes densidades de plantas. Revista Ciência Agronômica, Fortaleza, v. 36, n. 1, p. 82-90, 2005.

NAIM, A. M.; JABERELDAR, A. A. Effect of plant density and cultivar on growth and yield of cowpea (Vigna unguiculata (L.) Walp.). Australian Journal of Basic and Applied Sciences, Jordan, v. 4, n. 8, p. 3148-3153, 2010.

NAIM, A. M. et al. Determination of suitable variety and plants per stand of cowpea (Vigna unguiculata (L.) Walp.) in the sandy soil, Sudan. Advances in Life Sciences, Rosemead, v. 2, n. 1, p. 1-5, 2012.
NJOKU, D. N.; MUONEKE, C. O. Effect of cowpea planting density on growth, yield and productivity of component crops in cowpea/cassava intercropping system. Journal of Tropical Agriculture, Food, Environment and Extension, Nsukka, v. 7, n. 2, p. 106-113, 2008.

OLUFAJO, O. O.; SINGH, B. B. Advances in cowpea cropping systems research. In: FATOKUM. C. A. et al. (Eds.). Challenges and opportunities for enhancing sustainable cowpea production. Ibadan: IITA, 2002. v. 1, cap. 4, p. 267-277.

OROKA, O. O.; OMOREGIE, A. U. Competition in a rice - cowpea intercrop as affected by nitrogen fertilizer and plant population. Scientia Agricola, Piracicaba, v. 64, n. 6, p. 621-629, 2007.

PIMENTEL-GOMES, F. Curso de estatística experimental. 15. ed. Piracicaba, SP: NOBEL, 2009. $451 \mathrm{p}$.

QASEM, J. R.; BIFTU, K. N. Growth analysis and responses of cowpea [Vigna sinensis (L.) Savi Ex Hassk.] and redroot pigweed (Amaranthus retroflexus L.), grown in pure and mixed stands, to density and water stresses. The Open Horticulture Journal, Sharjah, v. 3, n. 1, p. 21-30, 2010.

SANTOS, M. G. Desempenho agronômico de feijão-caupi em função do espaçamento e densidade de plantas cultivado nos sistemas de várzea irrigada e cerrado. 2014. 48 f. Dissertação (Mestrado em Produção Vegetal: Linha de Pesquisa Fitotecnia) - Universidade Federal do Tocantins, Gurupi, 2014.

SAS INSTITUTE. SAS/STAT ${ }^{\circledR}$ 14.1 User's Guide. Cary, 2015. Disponível em: <http://support.sas.com/ documentation/cdl/en/statug/68162/PDF/default/ statug.pdf $>$. Acesso em: 26 jan. 2016.

TÁVORA, F. J. A. F.; NOGUEIRA, S. L.; PINHO, J. L. N. Arranjo e população de plantas em cultivares de feijão-de-corda com diferentes características de copa. Revista Ciência Agronômica, Fortaleza, v. 32, n. 1, p. 69-77, 2001.

ZIMMERMANN, F. J. P. Estatística aplicada à pesquisa agrícola. 2. ed. Brasília, DF: Embrapa; Santo Antônio de Goiás: Embrapa Arroz e Feijão, 2014. 582 p. 